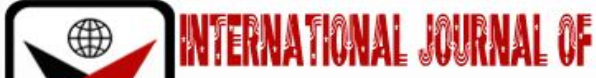

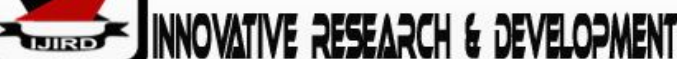

ISSN 2278 - 0211 (Online)

\section{Risk Analysis of the Company through Good Corporate as Intervening Business on Sustainable Company (Case Study on BEI Company Period 2011-2016)}

Said Djamaluddin
Lecturer, Mercu Buana University, Jakarta, Indonesia
Apollo
Lecturer, Mercu Buana University, Jakarta, Indonesia
Megawati Ariani
Alumni, Mercu Buana University, Jakarta, Indonesia

\section{Abstract:}

This study aims to examine risk analysis of the company through good corporate as intervening business on sustainable company (case Study on BEI Company Period 2011-2016. The sampling method used was purposive sampling. Population of 43 banking industry and there are 22 meet the criteria as a sample. The analytical method used structure equation models with warp PLS software. The result of study show liquidty coverage ratio, capital adequasi ratio and non performing loan have significant positive effect on good corporate governance. Capital adequasi ratio and good corporate governance have significant positive effect on sustainable company, but liquidty coverage ratio and non performing loan have no significant positive effect on sustainable company.

Keywords: Financial Risk, good corporate, Sustanable Company

\section{Introduction}

A company in the conduct of business activities often set the target strategy for the short and long term. Enterprises to achieve these goals the company must take risks, there is often a trade off between profit potential and risk. The higher the expected profit potential will be offset by a large potential risk as well. So in the risk assessment needs to be done carefully and measurable (can be quantified), not subjectively (based on perception), Hery (2015:6).

The implementation of continuous activities in each Bank in each period tends to increase and also decrease significantly. The highest achievement of sustainable activity was $91.2 \%$ in 2011 and the lowest continuous activity of 35.16 in 2016 as shown in Figure 1.

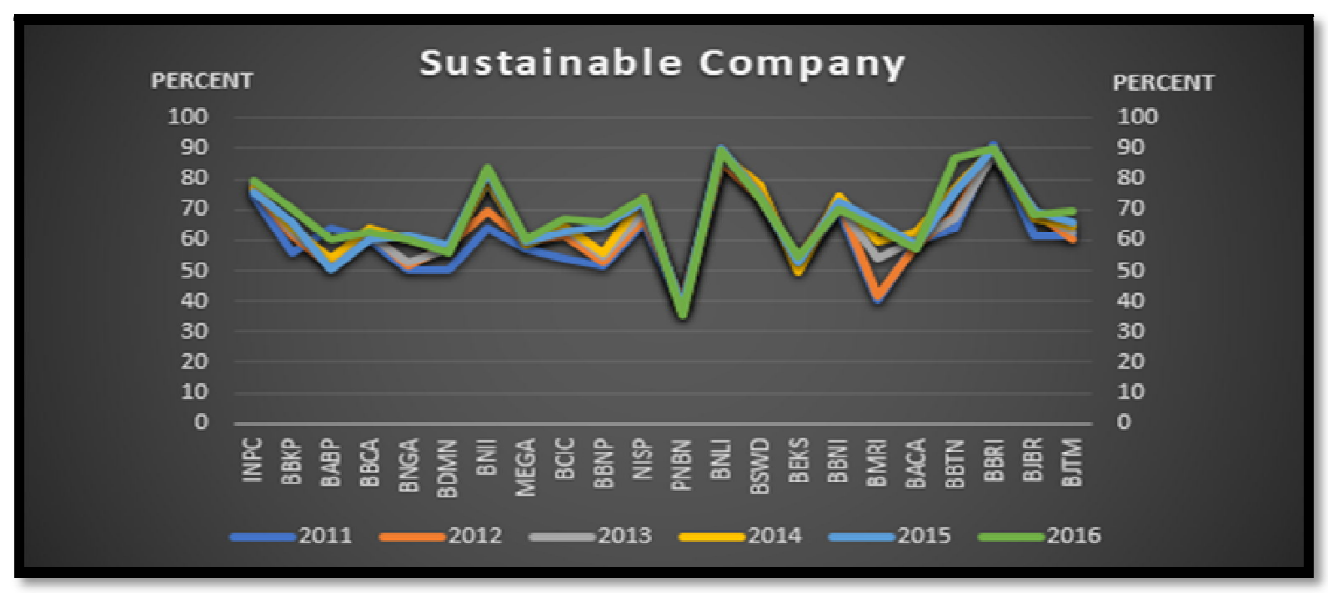

Figure 1 : Sustainable Development on Indonesian Banking 2011-2016 
Application of GCG especially in the management of the company as one of the most important efforts to produce a trusted company and able to make the company a sustainable company. GCG issues are becoming increasingly important because with the consistent application of GCG, countries and devices can create legislation that supports a healthy, efficient and transparent business climate, in addition to implementing these laws and consistently enforcing the law. Based on Graph 2 it can be seen how the progress of GCG activities report in each Bank in each period. The highest GCG reached 109.86\% by 2015, while the lowest GCG was 50.54\% in 2011.

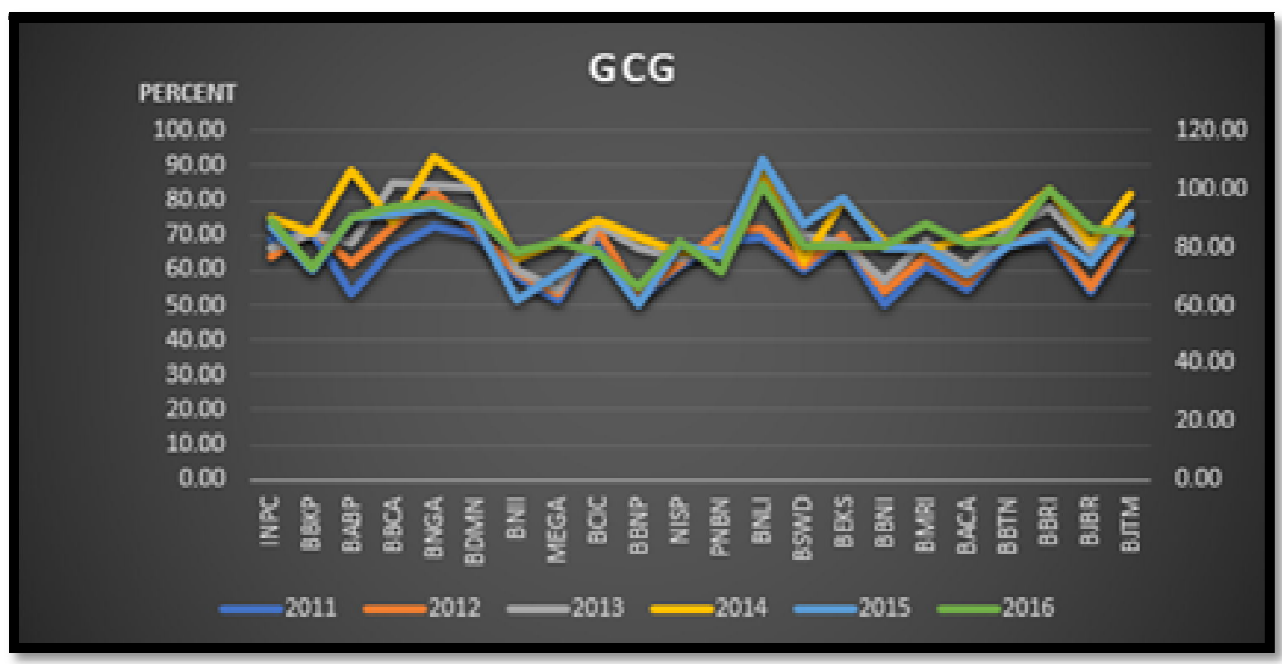

Figure 2 : Growth of Good Corporate Governance in Indonesian Banking 2011-2016

Capital Adequacy Ratio (CAR), which is a ratio to measure the capital adequacy of a bank to support assets that contain or generate risks, such as loans provided (Faisol, 2007). Capital is not only an important source to meet the bank's funding needs, but also the position of capital will affect the management decision-making and possible risks. Bank Indonesia Regulation No.15 / 12 / PBI / 2013 dated December 12, 2013 concerning the Minimum Capital Requirement for Commercial Banks, in order to create a sound and well-developed banking system and compete nationally and internationally, Banks need to improve their ability to absorb risk due to the excessive crisis and / or credit growth of banks through enhancing the quality and quantity of Bank capital in accordance with prevailing international standards Basel III. Based on Bank Indonesia Circular Letter No.13 / 24 / DPNP dated October 25, 2011, the capital adequacy assessment includes an assessment of the adequacy of capital and an assessment of the capital adequacy of the bank. Capital factor can be measured by using Capital Adequacy Ratio (CAR).

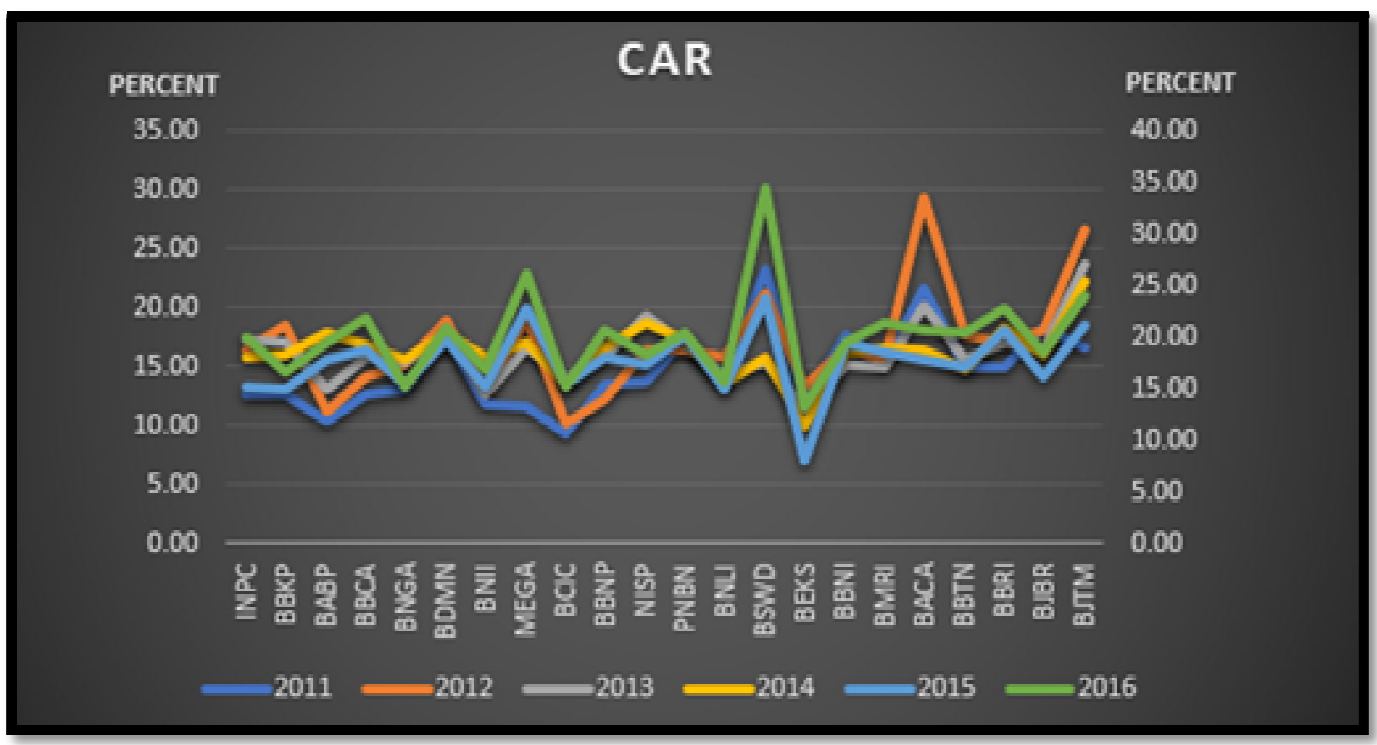

Figure 3 : The Development of Capital Adequacy Ratio in Indonesian Banking 2011-2016 
Based on Graph 3 it can be seen how the development of CAR ratio at Bank in each period. The Bank's capital adequacy ratio is still quite good, with CAR still above $8 \%$ as determined by Bank Indonesia (BI). The highest CAR reaches $34.50 \%$ in 2016, while the lowest CAR of 8.02\% in 2015. According to Dendawijaya (2009: 121) Capital Adequacy Ratio (CAR) is a ratio showing how far all bank assets that contain risks (credit inclusion, bill to other banks) to be financed from the bank's own capital fund

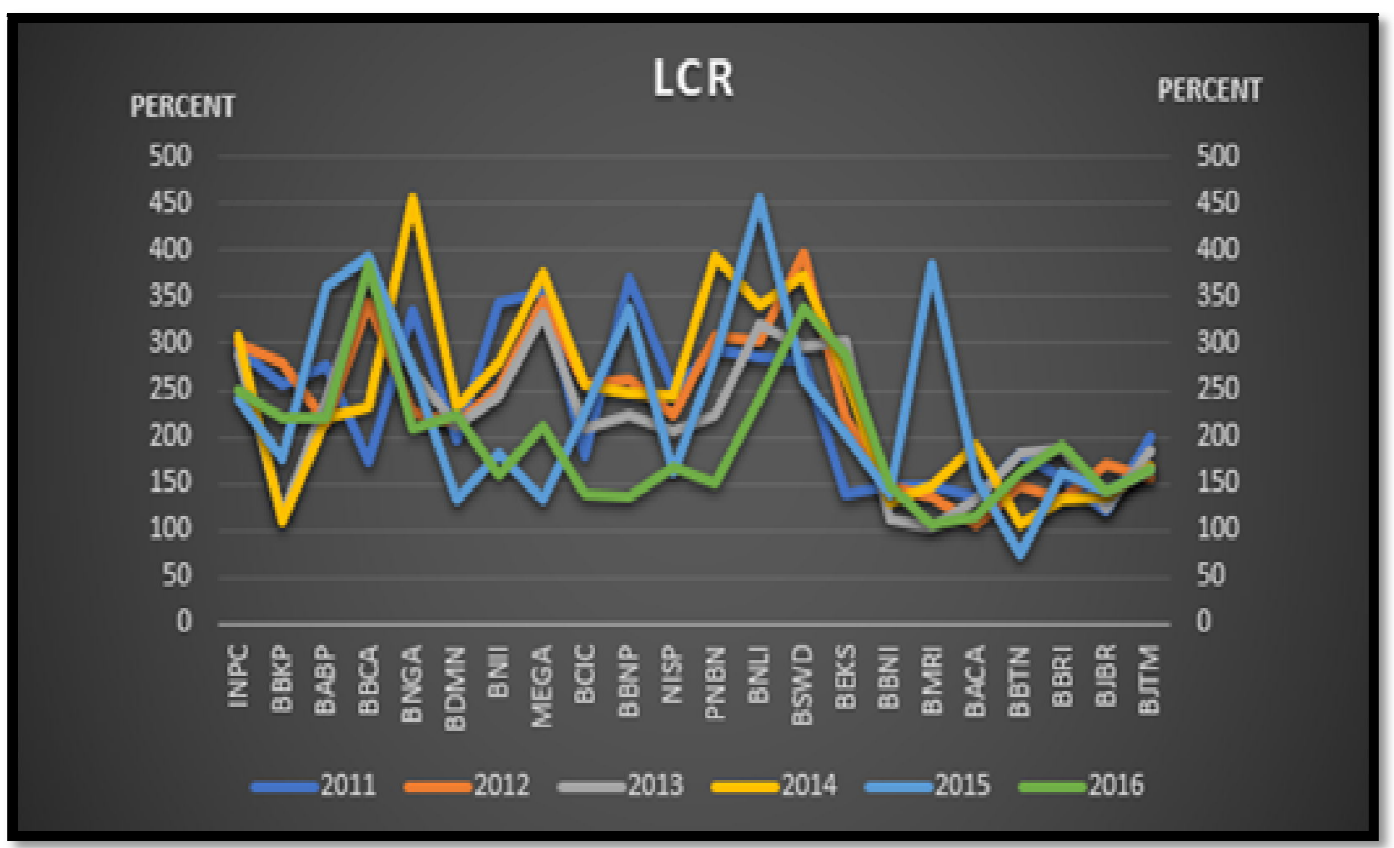

Figure 4 : The Development of Liquidity Coverage Ratio In Indonesian Banking 2011-2016

Specifically, LCR will issue as checked on January 1, 2015, but Minimum requirements will be set at $60 \%$ and in the same step reach 100\% 1 January 2019. this behavior, coupled with revisions made to 2010 Standard of liquidity publication, 3 is intended to ensure that LCRs can be published. Seeing the development of LCR ratio in graph 3 shows that the ratio of LCR also decreased and increased significantly. By 2015 the highest LCR ratio is achieved at the lowest 456\% by $73.70 \%$ in 2015.

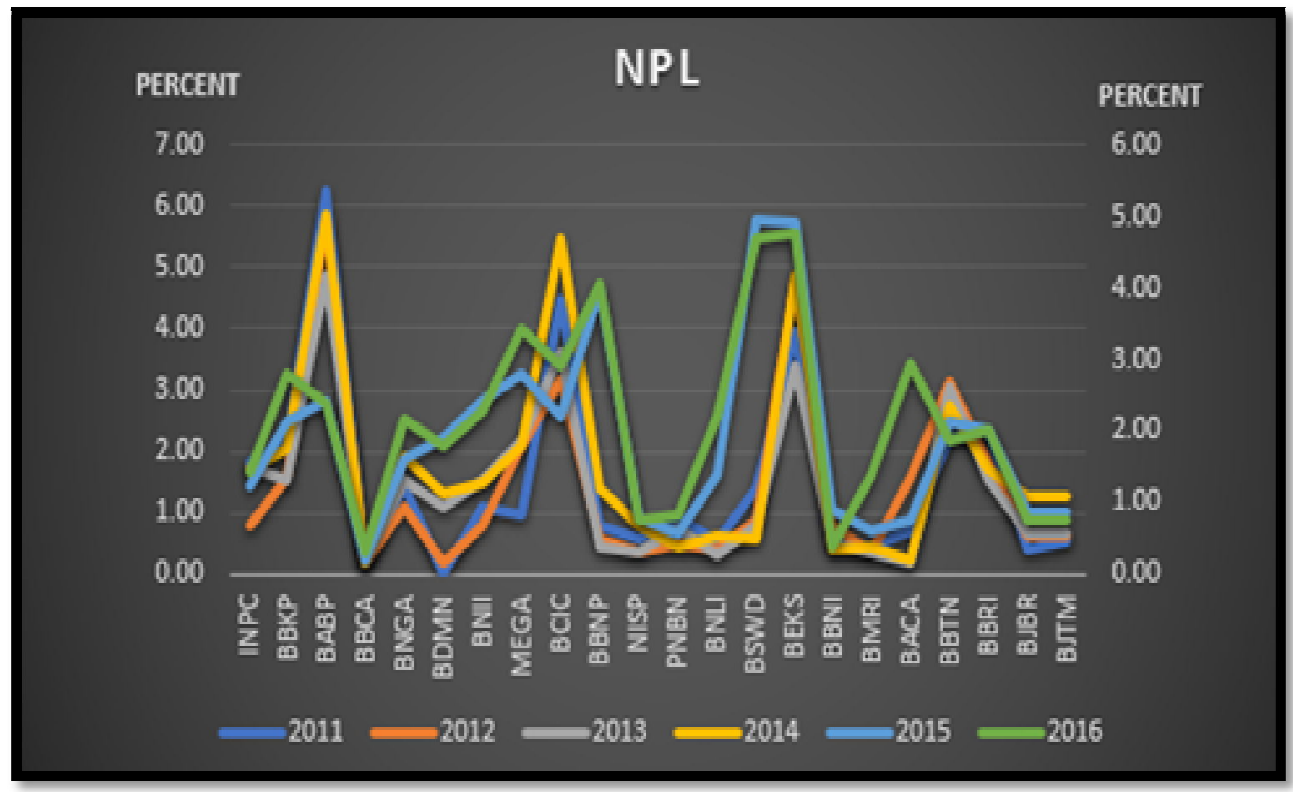

Figure 5 : Non-Performing Loan Development in Indonesian Banking 2011-2016

Based on Graph 5 it can be seen how the development of NPL ratio at Bank in each period. The highest NPLs reached $6.25 \%$ in 2011 , while the lowest NPL was $0.00 \%$ in 2011 . The sluggish economy followed by the decline in public purchasing 
power made business actors having difficulties in repaying loans and bank interest in making Non Performing Loan banking tends to increase.

\section{Literature Review}

Wibisono (2007), said that the business world is increasingly realizing that the company is no longer faced with the responsibility on the single bottom line, which is the corporate value reflected in the financial condition, but must pay attention to social and environmental aspects. In achieving success in an uncertain business environment companies must formulate a consistent strategy. Organizational environment is a very important variable in determining the business strategy of a company. From here comes the concept of a strategy that is a plan, action that will develop a company's competitive advantage (Ellitan, 2008). According to Craig (1996), a strategy identifies the approach used to accomplish goals. In addition, strategies can be explicitly defined and reflected in decisions made and actions taken. The formal definition of the strategy itself is the art of designing a plan that holds the capabilities and competencies of an organization focused on the environment of Theory, Stakeholder Theory and Legitimacy Theory, and theory of the triple bottom line.

The complete Sustainability Report can be defined on the Reports issued by the company to disclose the company's performance on the economic, environmental and social aspects, as well as the company's efforts to become an accountable company for all stakeholders for the performance of the company towards sustainable development . The purpose of making this Sustainability report is to communicate the company's economic, environmental, and social commitments and economic performance to stakeholders and the broader community in a transparent manner. Through this report the stakeholders can get a clearer and more open picture of all the sustainable development activities that the Company has undertaken.Various thoughts on corporate governance are developed based on agency theory where management is carried out in full compliance with various rules and regulations (Kaihatu, 2006). These efforts create what are called agency costs. In agency theory, corporate governance is needed because of the relationship between the principal (owner of capital / shareholders) and the agent (management) and conflict arising from the relationship of both parties.

In agency theory, corporate governance arises from the company's interest to ensure to the principal / investors that the funds invested are used appropriately and efficiently. In addition, with corporate governance, the company gives assurance that the management acts best for the company's interests. The implementation of the concept of corporate governance is expected to give trust to the agent (management) in managing the wealth of the owner (investor), and the owner becomes more confident that the agent will not commit a fraud for the welfare of an agent. The emerging agency problem between principal and agent encourages the implementation of good corporate governance which is expected to minimize the potential of fraud (Kamyarta, 2007). Based on the General Guidelines of Good Corporate Governance of Indonesia, issued by the National Committee on Governance Policy (KNKG, 2006), there are 5 principles of good corporate governance. The five principles are transparency, accountability, responsibility, independence and fairness and equality. Principles of good corporate governance according to Bank Indonesia Regulation no. 8/ 4 / PBI / 2006 on the Implementation of Good Corporate Governance for Commercial Banks, including: Transparency, Accountability, Responsibility, Independency and Fairness (TARIF).

According to Kasmir (2013: 128) liquidity ratio is the inability of the company to pay its obligations, especially shortterm (which is due) caused by various factors, namely: Could be because the company is not having funds at all, or Could maybe the company has funds, but at maturity the company does not have the funds (not enough funds in cash so it has to wait in a certain time, to disburse other assets such as collect receivables, sell securities, or sell other supplies or assets). The LCR framework is applied to all conventional commercial banks including Branch Offices of Foreign Banks, with gradual implementation time. Banks may use their shares of High Quality Liquid Assets (HQLA) either exclusively or systemic stress events, although supervisory responses may vary between the minimums, the bank must provide an assessment of its liquidity position.

According to Dendawijaya (2009: 121) Capital Adequacy Ratio (CAR) is a ratio that shows how far all bank assets that contain risks (credit inclusion, securities, bills with other banks) to be financed from the bank's own capital funds. Capital Adequacy Ratio (CAR), which is a ratio to measure the capital adequacy of a bank to support assets that contain or generate risks, such as loans provided (Faisol, 2007). Capital is not only an important source to meet the bank's funding needs, but also the position of capital will affect the management decision-making and possible risks. Kasmir (2010:232) The definition of the capital adequacy ratio can be defined as the ratio used to measure capital and reserve delays in loan obligations, especially those that occur because interest fails to be collected. Capital is a major factor for banks to grow their business. Capital is used to assess how much the bank's ability to bear the risk that may occur. Banks that have high risk levels will be more resolvable. Conversely, banks that have little risk to identify banks are less solvable. High capital levels will increase the cash reserves that can be used to expand credit, so a high level of solvency will open up bigger opportunities for banks to increase profitability. Conversely, banks with low solvency levels will reduce the ability of banks to increase profitability, even reduce public confidence, so that will affect the continuity of their business. Changes in Bank Indonesia regulation on the implementation of Risk Management for Basel II Commercial Banks to Basel III, minimum capital (KPMM) from 8\% increase $+2.5 \%$ to $10.5 \%$. According Riyadi (2006) NPL ratio is the ratio between the amount of loans granted to the level of collectibility which is a problem loans compared with the total loans provided by the bank. The same is stated by Shingjergii and Hyseni (2015) that "NPL ratio is part of bank credit management, because the credit problem itself is a risk faced by all banking services 
companies. Credit risk is a risk faced by banks in relation to the amount of credit disbursed to customers where the greater the amount of credit disbursed the greater the credit risk.

Prior research by Ratnovski (2013) suggests that LCR has a significant positive effect on GCG. Ihsan (2016) the result of his research is a significant positive relationship between CAR and GCG. The results of research conducted by Ratih (2013) showed that NPL has a significant positive effect on GCG.

The results of research conducted by Shah (2013) showed a significant positive relationship LCR to sustainability. Pan and $\mathrm{Gu}$ (2013) in its research CAR has a significant positive relationship with banking sustainability. Results of research conducted by Kurniawansyah and Mutmainah (2013) showed significant significant NPL to Sustainability. The results by Roziq and Danurwenda (2015) discussed a significant positive GCG relationship to sustainability.

Based on previous research, then the framework of thought research was described as follows:

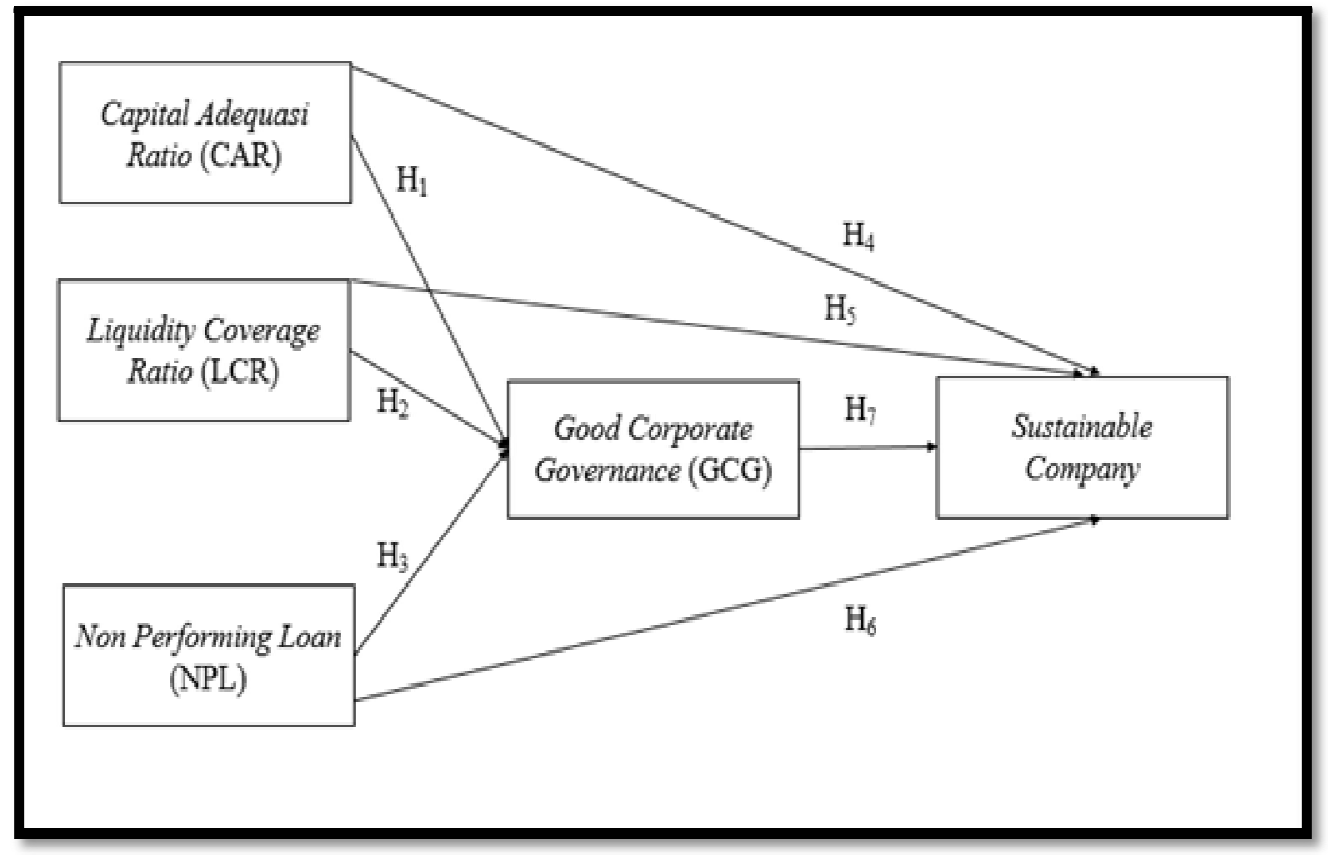

Figure 6: The Framework of Thought

There is a significant positive relationship between CAR and GCG Ihsan (2016). According to Dendawijaya (2009: 121) Capital adequacy ratio (CAR) is a ratio that shows how far all bank assets that contain risks (credit inclusion, securities, bills with other banks) to be financed from the bank's own capital funds. Hypothesis $\mathrm{H} 2$ taken in this study, namely:

- $\mathrm{H}_{1}$ : Capital adequacy ratio (CAR) has a significant positive effect on good corporate governance (GCG).

LCR has a significant positive effect on GCG Ratnovski (2013) To manage this risk, banks can accumulate a liquid asset buffer, or strengthen the liquidity requirements transparency can compromise bank transparency options, and increase refinancing risk. Hypothesis $\mathrm{H1}$ taken in this study, namely:

- $\mathrm{H}_{2}$ : Liquidity coverage ratio (LCR) has a significant positive effect on good corporate governance (GCG).

The results of the NPL have a significant positive effect on GCG Ratih (2013). The results of the research on the hypothesis show that the positive value generated from the implementation of good corporate governance is maximized by the perpetrators of banking companies means that the emergence of credit risk as the biggest risk in the world of banking in well managed, so the company's goal in achieving the performance expected by the stakeholders and shareholders can be achieved. Hypothesis H4 taken in this study, namely:

- $\quad \mathrm{H}_{3}$ : Non Performing Loan (NPL) has a significant positive effect on good corporate governance (GCG).

Shah (2013) resulted in a significant positive LCR relationship to sustainability. cost savings can reduce bank liquidity risk in the long term. Therefore, bank cost efficiency must be taken into account by policy makers in formulating liquidity risk management to ensure the sustainability of the banking system. Shah (2013) research results show a significant positive relationship LCR to sustainability. Banking is considered a sustainable sector in the global financial system. Hypothesis H5 taken in this study, namely:

- $\quad \mathrm{H}_{4}$ : Liquidity coverage ratio (LCR) has a significant positive effect on sustainable company

Pan and Gu (2013) research results show a significant positive relationship CAR to sustainability. In line with this, Sarwono and Sunarko (2015) test results also show that CAR has a significant positive effect on sustainibilty. The influence of CAR's variance on Sustaibility Financial signifies that the bigger banking companies in the banking industry can improve the sustainability of the bank. Hypothesis H6 taken in this study, namely:

- $\mathrm{H}_{5}$ : Capital adequacy ratio (CAR) has a significant positive effect on sustainable company 
Kurniawansyah and Mutmainah (2013) The results showed that NPL has a significant positive effect on Sustainability. Yam (2016) This study explores the impact of macroeconomic and bank specific factors on the performance of non performing loans (NPLs) and banking sustainability performance (BPRS) results showed NPL has a significant positive effect on Sustainability. Kurniawansyah and Mutmainah (2013) NPL have a significant positive effect on Corporate Social Responsibility activities. Hypothesis H8 taken in this study, namely:

- $\mathrm{H}_{6}$ : Non Performing Loan (NPL) has a significant positive effect on sustainable company

Roziq and Danurwenda (2015) GCG significant positive relationship to sustainability. Hypothesis H9 taken in this study, namely:

- $\quad \mathrm{H}_{7}$ : Good corporate governance (GCG) has a significant positive effect on sustainable companies

\section{Research Methods}

In accordance with the purpose of research is to test the hypothesis, the research design used in this study is to use explanative method of explaining causal relationships. The type of research is causal, referring to Sugiyono (2013: 56) causal relationships are causal relationships, so there are independent variables (variables that affect) and dependent (variables that are affected).

The population in this study is a banking company listed on the Indonesia Stock Exchange (IDX) successively during the year 2011-2016. Samples in this study is selected banking sector companies using purposive sampling method with a total sample of 132 data.

\begin{tabular}{|c|c|c|c|}
\hline Variables & Indicator & Measurement & Scale \\
\hline Liquidity Risk & $\begin{array}{l}\text { Liquidty Coverage } \\
\text { Ratio (LCR) }\end{array}$ & $\frac{\text { Stok HOLA }}{\text { Total Net Cash OutFlows dalam 30 hari ke depan }} \geq 100 \%$ & Ratio \\
\hline Financial Risk & $\begin{array}{l}\text { Capital Adequasi } \\
\text { Ratio (CAR) }\end{array}$ & $\mathrm{CAR}=\frac{\text { Modal }}{\begin{array}{c}\text { Aktiva Tertimbang } \\
\text { Menurut Risiko (ATMR) }\end{array}} \times 100 \%$ & Ratio \\
\hline $\begin{array}{l}\text { Credit } \\
\text { Risk }\end{array}$ & $\begin{array}{l}\text { Non Performing } \\
\text { Loan (NPL) }\end{array}$ & $N P L=\frac{\text { Total Kredit Bermasalah }}{\text { Total Kredit }} \times 100 \%$ & Ratio \\
\hline $\begin{array}{c}\text { Good Corporate } \\
\text { Governance (GCG) }\end{array}$ & $\begin{array}{c}\text { Good Corporate } \\
\text { Governance (GCG) }\end{array}$ & Total score $=$ Level 1 score + Level 2 score & Index \\
\hline $\begin{array}{l}\text { Sustanability } \\
\text { Company }\end{array}$ & Sustanability & GRI-G4 & Index \\
\hline
\end{tabular}

Table 1: Research Variables

Technique of data analysis in this study using partial at least square. Modeling of Partial Least Square Structural Eqution (PLS-SEM) often called PLS is a method to test the relationship between latent construct with linear or non linear relationship with many good indicators Reflective or formative.

Exogenous variables are Capital Adequacy Ratio (CAR), Liquidty Coverage Ratio (LCR), and Non Performing Loan (NPL), endogenous variable of Good Corporate Governance (GCG) as well as variable intervening and endogenous two Sustanability Companies. The intervening variable is a variable based on its relation with the endogenous variable, whether the variable is related or not to the endogenous variable, Ghozali (2013: 224). Furthermore can be formed equation or structural equation as follows:

Equation:

$\eta 1=\beta 1 \xi 1+\beta 2 \xi 1+\beta 3 \xi 1+\beta 4 \xi 1+\zeta_{1}$

$\eta 2=\beta 5 \xi 1+\beta 6 \xi 1+\beta 7 \xi 1+\beta 8 \xi 1+\beta 1 \eta 1+\zeta 2$

Explanation:

छ1 : Variabel eksogen Capital Adequasi Ratio (CAR)

६2 : : Variabel eksogen Liquidty Coverage Ratio (LCR)

¡3 : Variabel eksogen Non Performing Loan (NPL)

$\eta 1$ : Variable endogen one (intervening), Corporate Governance (GCG)

$\eta 2$ : Variabel Sustanability Company

$\beta_{1} \xi_{1}-\beta_{8} \xi_{4}, \beta_{1} \eta_{1}$ : koefisien path

$\zeta 1, \zeta 2$ : measurement error for latent variables in each endogenous variable

Assessment in PLS for the secondary data used is structural model. Structural model (inner model) to predict the relationship between latent variables by looking at how much the variant can be explained and to know the significance of $p$ value. In the structural model with PLS, the assessment can be by looking at the large percentage variance described, R- 
squares for each endogenous latent variable as the predictor strength of the structural model, to test predictive relevance, and the overall model.

\section{Results and Discussion}

\subsection{Results}

Data processing in this study was conducted using the help of software WarpPLS 5.0, the results of model analysis is often referred to as a structural model or inner model.

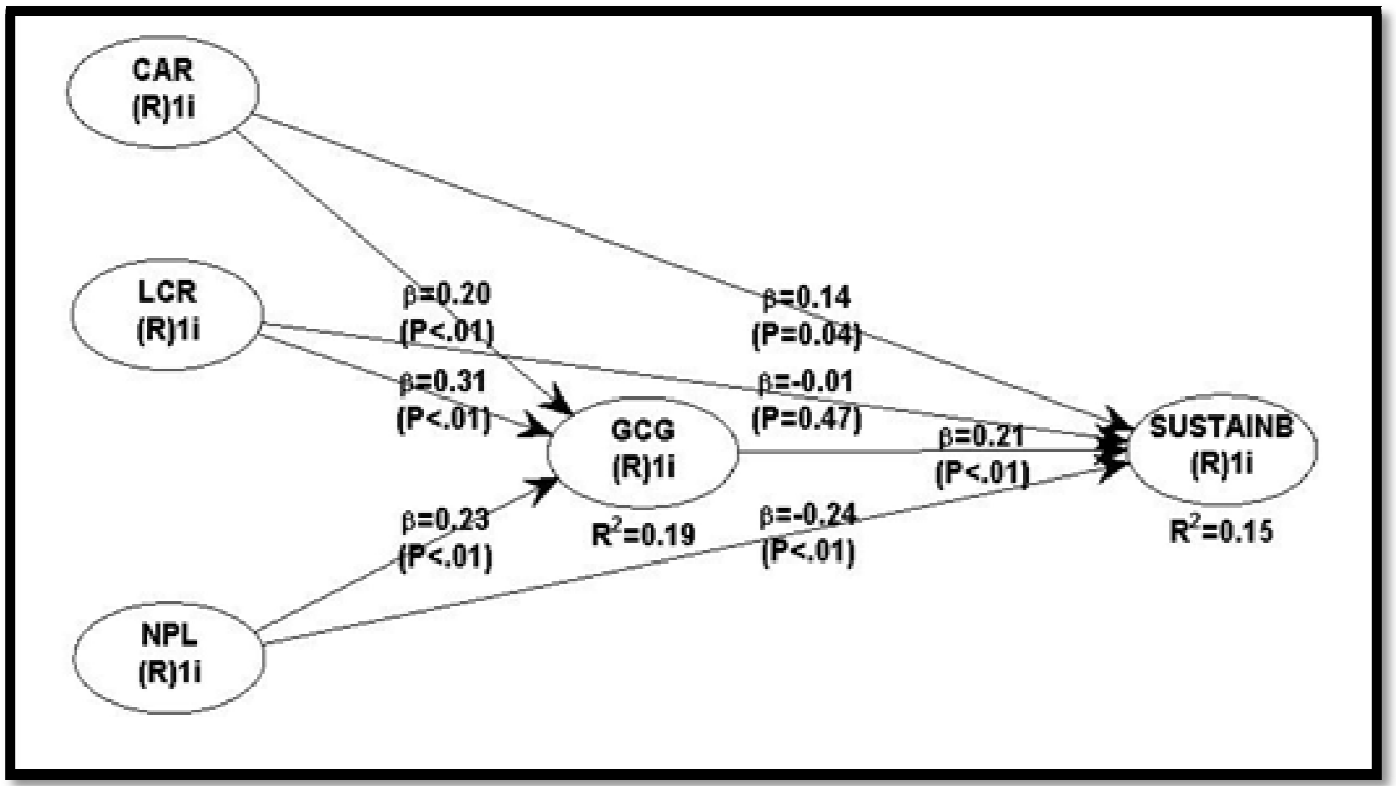

Figure 7: Model Estimation Results Source: Processed Data (2018)

\begin{tabular}{|c|c|c|c|c|}
\hline No. & Hipotesis & *Pvalue & Koefisien & Keterangan \\
\hline $\mathrm{H}_{1}$ & CAR has an effect on GCG & 0.01 & 0.20 & Significant, $\mathrm{H}_{2}$ Accepted \\
\hline $\mathrm{H}_{2}$ & LCR has an effect on GCG & 0.01 & 0.31 & Significant, $\mathrm{H}_{1}$ Accepted \\
\hline $\mathrm{H}_{3}$ & NPL has an effect on GCG & 0.01 & 0.23 & Significant, $\mathrm{H}_{4}$ Accepted \\
\hline $\mathrm{H}_{4}$ & LCR has an effect on Sustainable & 0.47 & 0.01 & $\begin{array}{c}\text { Not significant, } \\
\mathrm{H}_{5} \text { Rejected }\end{array}$ \\
\hline $\mathrm{H}_{5}$ & CAR has an effect on Sustainable & 0.04 & 0.14 & Significant, $\mathrm{H}_{6}$ Accepted \\
\hline $\mathrm{H}_{6}$ & NPL has an effect on Sustainable & 0.01 & -0.24 & $\begin{array}{c}\text { Not significant, } \\
\mathrm{H}_{8} \text { Rejected }\end{array}$ \\
\hline $\mathrm{H}_{7}$ & GCG has an effect on Sustainable & 0.01 & 0.21 & Significant, $\mathrm{H}_{9}$ Accepted \\
\hline
\end{tabular}

Table 2: Hypothesis Testing Results

*P Value Standar $₫ 0.05$

The result of structural model evaluation refers Ghozali (2014: 106), can be interpreted as follows:

\begin{tabular}{|c|c|c|c|c|c|c|}
\hline No & Indeks Penilaian & LCR & CAR & NPL & GCG & Sustainability \\
\hline 1 & R-squared & & & & 0.188 & 0.150 \\
\hline & Adjusted R-squared & & & & 0.169 & 0.123 \\
\hline 2 & Full collinearity VIF & 1.052 & 1.113 & 1.062 & 1.117 & 1.052 \\
\hline 3 & Q-squared & & & & 0.206 & 0.163 \\
\hline 4 & Goodn & Fit T & is & 411 & & \\
\hline
\end{tabular}

Table 3: Results of Structural Model Evaluation

The result of evaluation of structural model in Table 3 can be seen R-squared value for endogenous variable of GCG of 0.188 and endogenous variable of Sustainbility is 0.150 . For the estimation used can be R-squared or adjusted R-squared. The 
result of R-squared adjusted value analysis for endogenous variable GCG 0.169 and adjusted R-squared is for endogenous variable of Company Sustainability is 0.123 , hereinafter can be explained as follows:

- The results of this study are estimates using R-squared values. R-squared GCG can be explained by exogenous variable of Liquidty Coverage Ratio (LCR), Capital Adequacy Ratio (CAR) and Non Performing Loan (NPL) equal to 0.188 (19\%), mean influence of $\varangle 0.25$, fall into the weak category. The remaining effect of $81 \%(100 \%-19 \%)$ is the influence of other factors not included in the study.

- R-squared endogen both can be concluded Sustanability Bank can be explained by exogenous variable Liquidty Coverage Ratio (LCR), Capital Adequacy Ratio (CAR), Loan Loss Provisioning (LLP) and Non Performing Loan (NPL) and variable endogen one variable Good Corporate Governance GCG) of 0.150 (15\%), the effect indicates weak category. The remaining influence of $85 \%(100 \%$ - 15\%) is the value of full collinearity VIF for Liquidty Coverage Ratio (LCR) 1.052, Capital Adequacy Ratio (CAR) 1,113 and Non Performing Loan (NPL) 1.062, endogenous variable one variable Good Corporate Governance (GCG) of 1,117 and endogen two sustainability of the company amounted to 1,052. All latent variables show $<3.3$ which means that there is no multicollonearity problem between latent variables.

- The value of Q square result of analysis for Good Corporate Governance (GCG) variable is 0.230 and sustainability is 0.163. According to (Stone and Geisser 1974) in (Ghozali 2014: 356) if the value of Q square generated by any endogenous variable $>0$ then it can be interpreted that the model has predictive relevance.

- The goodness of fit (GoF) value of the WarpPLS model for secondary data does not take into account the overall optimization, so in the study take one of the GoF sizes of Tenenhaus goodness of fit. Assessment of analysis for goodness of fit used is when $\mathrm{GoF}$ is, small $>0.1$, medium $>0.25$, large $>0.36$. The results of the research analysis of 0.411 , thus can be interpreted Tenenhaus goodness of fit results into a large category.

\subsection{Discussion}

\subsubsection{Effect of Capital Adequasi Ratio to Good Corporate Governance}

Based on the results of analysis using PLS approach, obtained the result that the coefficient of capital adequacy ratio to good corporate governance has a coefficient value of 0.20 , while the value of pvalue $\varangle 0.01$. The second hypothesis in this research is CAR influence on good corporate governance, so H2 research accepted. This shows that CAR has significant positive effect to good corporate governance, which means that if Capital Adequacy Ratio (CAR) increases then it can improve good corporate governance. Capital adequacy ratio is a ratio to measure the capital adequacy of a bank to support assets that contain or generate risks.

The research was supported by previous researcher Dendawijaya (2009: 121), with the findings of the research there is a significant relationship between CAR and corporate governance.

The study is not in line with Sudrajat (2017), Capital Adequacy Ratio (CAR) has no significant effect on Corporate Governance and disclosure of Islamic Social Reporting (ISR).

\subsubsection{Effect of Liquidity Coverage Ratio to Good Corporate Governance}

Based on the results of analysis using partial least square software tools, the results obtained that the coefficient of liquidity coverage ratio to good corporate governance has a coefficient value of 0.31 , while the value of $p$ value $\varangle 0.01$. The first hypothesis in research is liquidity coverage ratio to good corporate governance, so H1 research accepted. This shows that liquidity coverage ratio (LCR) has a significant positive effect on good corporate governance, which means that if liquidity coverage ratio increases then good corporate governance will be better.

The results of this study support previous research conducted by Ratnovski (2013), the results of liquidity research affect the governance company. To manage this risk, banks can accumulate a liquid asset buffer, or strengthen the liquidity requirements transparency can compromise bank transparency options, and increase the risk of refinancing.

\subsubsection{Effect of Non Performing Loan to Good Corporate Governance}

Credit risk ratio is the ratio used to measure the risk to credit disbursed by comparing bad debts with the amount of credit disbursed. Based on the results of analysis, obtained the coefficient of NPL to Good Corporate Governance (GCG) has a parameter value of 0.23 , pvalue value $\varangle 0.01$. Fourth hypothesis in this research is NPL influence to good corporate governance, so H4 research accepted. This shows that non-performing loans have a significant positive effect on Good Corporate Governance (GCG), thus it can be concluded that non performing loan is increasing, it can still support Good Corporate Governance.

Implementation of good corporate governance which in this research give positive value for company to be able to assist banking company to control the giving of credit to the debtor, it is seen from result of sample which used mostly have value of NPL which is under limit of stipulation determined by BI, that is Gross NPL of $5 \%$.

The results of this study support previous research conducted by Ratih (2013) non-performing loans have a significant positive effect on Good Corporate Governance (GCG). Another researcher Lai (2014) findings is that non-performing loans (NPLs) are not significantly related to corporate governance. 


\subsubsection{Effect of Capital Adequasi Ratio Terhadap Sustainable Company}

Based on the analysis, the capital adequacy ratio (CAR) coefficient on Sustainability has a parameter value of 0.14 with pvalue value $<0.04$. The sixth hypothesis of the study is accepted so that it can be concluded that capital adequacy ratio (CAR) has a significant positive effect on Sustainability Bank, which means that capital adequacy ratio will increase Sustainability Bank. The higher the capital adequacy ratio (CAR), the better the sustainability of the Bank. capital adequacy ratio (CAR) by Bank Indonesia is called the Bank's Minimum Capital Requirement (KPMM). It describes the CAR represents the amount of capital ownership that should be included in the banking operations. The existence of CAR will be indispensable in banking expansion activities.

The results of this study support previous research conducted by Yam (2016), with the findings of capital adequacy ratio positively affecting Banking Sustainability Research also conducted by Pan and Gu (2013) Capital adequacy ratio (CAR) has a positive relationship with banking sustainability. To strengthen risk management, CAR is a requirement of the stability of sustainable development of commercial banks The study is not in line with Sudrajat (2017), Capital Adequacy Ratio (CAR) has no significant effect on CSR.

\subsubsection{Effect of Liquidity Coverage Ratio to Sustainable Company}

Based on the results of analysis using PLS analysis, the results obtained that the coefficient of LCR to Sustainability has a parameter value of -0.01 , while the value pvalue test $0.47>0.10$. The fifth hypothesis in this study is that LCR has no effect on Sustainability Bank, so it can be decided that $\mathrm{H} 5$ research is rejected. The result of the research shows that liquidity coverage ratio (LCR) has no significant effect to the sustainability of the Company, thus it can be concluded that the asset has not been utilized or still settles so that the company's role towards sustainability is not optimal and effective. The company has not fully implemented sustainability program so that the ratio will disrupt the company performance.

The results of this study are not in line with previous research conducted by Khalib et.al (2016), with the results of research liquidity coverage ratio has a significant positive impact on sustainability banking. The next researcher Shah (2013) with the results of research liquidity coverage ratio has a significant positive effect with the sustainability of the banking sector.

\subsubsection{Effect of Non Performing Loan Terhadap Sustainable Company}

Based on the analysis using the approach that has been done, the results obtained that the coefficient of Non Performing Loan against Sustainability has a negative coefficient of -0.24 with pvalue $<0.01$. The eighth hypothesis in this study is NPL is not significant to Sustainability Bank, so it can be taken decision that H0 research accepted. This shows that Non Performing Loan has no significant effect on Sustainability Bank. Thus, the NPL ratio indicates that the Bank's management capability in managing non-performing loans provided by the Bank does not affect the Bank's ability to go concern. The company can not fulfill its performance optimally, a lot of money is stuck outside and unproductive so the company has a slow acceleration and sustainability impaired company.

Research supports previous research that is Miah and Alam (2017) and Idoliany and Wiryono (2014) Non Performing Loan no negative effect on Sustainability.

The results of this study do not support previous research conducted by Hue (2015) Non Performing Loan positively affect Sustainability Commercial Banks ..

\subsubsection{Effect of Good Corporate Governance Terhadap Sustainable Company}

Based on the results of analysis using PLS analyst, the results obtained that the coefficient of Good Corporate Governance to Sustainability has a parameter value of 0.21 , while the value pvalue $\varangle 0.01$. The ninth hypothesis in this study is GCG influence on Sustainability Bank, showing that GCG has a significant positive effect to Sustainability Bank. Thus it can be concluded, if Good Corporate Governance is better and improved it can improve Sustainability Bank. The results of this study in accordance with the theory that explains that the implementation of Sustainability is not independent of the application of the concept of Good Corporate Governance within the company itself.

The results of this study support previous research conducted by Roziq and Danurwenda (2015) Good Corporate Governance have a significant positive effect on Corporate Social Responsibility Bank the better the corporate governance done by the Bank, the higher the Sustainability of the bank. Other researchers who also showed the results of Good Corporate Governance have a significant positive effect on Corporate Social Responsibility Bank is Golja at.al (2011) and Pitelis (2011).

\section{Conclusion}

Based on the results of data analysis and discussion that has been done, it can be concluded as follows:

Liquidity coverage ratio has a significant positive effect on good corporate governance, the higher the liquidity it can improve good corporate governance the better. The influence of the strongest variable is shown by the influence of liquidity coverage ratio to good corporate governance. Capital adequacy ratio has a significant positive effect on good corporate governance, it can be concluded if the liquidity coverage ratio increases then it will be able to improve good corporate governance. Non-performing loans have a significant positive effect on good corporate governance, if non-performing loan increases, it will improve good corporate governance. 
Liquidity coverage ratio has no significant effect to sustainable company, which means that if assets are not utilized optimally and effectively, the company has not fully implemented sustainability program. but influential when through good corporate governance is good. Capital adequacy ratio has a significant positive effect on sustainable company, the higher the capital adequacy ratio the better the sustainability of the Bank concerned. The influence of the strongest variable on Sustainable Bank is shown by the effect of impairment losses. Non-performing loans have no significant effect on sustainable companies, non-performing loans that are not able to support sustainability, but influential when through good corporate governance. Good corporate governance has a significant positive effect on sustainable companies, good corporate governance is better and improved it can improve Sustainability Bank.

\section{Expressed as Follows}

Become information and inputs for issuers in improving the implementation of good corporate governance and Bank Sustainability. Suspension may increase or alter with other variables that may affect good corporate governance and Bank Sustainability.

\section{References}

i. Agustiyanti.Jaga Likuiditas, Bank Penuhi Ketentuan LCR.Rabu,6 Januari 2016 | 20:01 WIB. www.id.beritasatu.com http:/ / id.beritasatu.com/ home/ jaga-likuiditas-bank-penuhi-ketentuan-lcr/ 136864

ii. Ahmad, MI; Guohui1 W, Hassan M, Naseem MA, dan Rehman R. ( 2016). NPL and Corporate Governance: A Case of Banking Sector of Pakistan. Accounting and Finance Research. Vol. 5, No. 2; 2016.

iii. Almilia, Luciana Spica; Shonhadji,Nanang dan Angraini. Faktor-Faktor yang Mempengaruhi Financial Sustainability Ratio pada Bank Umum Swast Nasional Non Devisa Periode 1995-2005. Jurnal Akuntansi Dan Keuangan. Vol.11, NO.1, pp.42-52.

iv. Anthony Saunders and Marcia Millon Cornett. (2008). Financial Institutions Management A Risk Management Approach. Sixth Edition. McGraw-Hill Companies. New York.

v. Ariestya, Putu Yutika dan Ardiana, Putu Agus. (2016). Implementasi Good Corporate Gonernance Pada Kinerja Perusahaan Sektor Keuangan Dengan Manajemen Risiko Sebagai Variabel Intervening. E-Jurnal Akuntansi Universitas Udayana. Vol.16.2.pp.1461-1488.

vi. Babalola, Adeyemi dan Adedipe, Oluwaseyi Ayodele. (2014). Corporate Governance and Sustainable Banking Sector: Evidence from Nigeria. Research Journal of Finance and Accounting. Vol.5, No.12, 2014.

vii. Bank indonesia. Direktorat Penelitian dan Pengaturan Perbankan(2009). Manajemen Risiko Likuiditas untuk Perbankan di Indonesia. Consultative paper. Jakarta.

viii. Bank Indonesia. 2004. Surat Edaran Bank Indonesia No 6/23/DPNP tentang Penilaian Tingkat Kesehatan Bank Umum. Jakarta. Bank Indonesia.

ix. Bessis, Joel. (2015) .Risk Management In Banking, $4^{\text {th }}$ ed. TJ International Ltd, Padstow, Cornwall. United Kingdom.

x. Bessis, Joël. (2015). Risk Management in Banking. Fourth edition. John Wiley \& Sons, Ltd, United Kingdom.

xi. Brigham dan Houston. 2006. Dasar-Dasar Manajemen Keuangan. Salemba Empat. Jakarta.

xii. Brigham, Eugene F. and Daves, Phillip R.. (2007). Intermediate Financial Management. 9th ed. Thomson/SouthWestern, a part of The Thomson Corporation. United States of America.

xiii. Chatzigakis, Nikiforos. (2016). How the replacement of basel II by basel III has an effect on economic growth. Regional Science Inquiry, Vol.VIII,No.3,pp. 147-157.

xiv. Chin, W.W. 1998. The Partial Least Square Approach for Structural Equation Modeling. Modren Methods for Business Research pp. 295-336, Hillsdale, New Jersey:Lawrence Erlbaum Associates.

xv. CohenJ. 1988. Statistical Power Analysis for the Behavioral Sciences. Hillsdale, New Jersey: Lawrence Erlbaum Associates.

xvi. Collard,Fabrice; Habib Michel., Rochet, Jean-Charles. (2015). Sovereign Debt Sustainability in Advanced Economies. Journal of the European Economic Association, Vol.13, Pp. 381-420.

xvii. Cornee, Simon dan Szafarz, Ariane. (2014).Vive la Difference: Social Banks and Reciprocity in the Credit Market.J Bus Ethics. Vol.125, pp.361-380.

xviii. Damayanti, Dhita Dhora dan Chaniago, Herizon. (2014) .Pengaruh Risiko Usaha Dan Good Corporate Governance Terhadap Skor Kesehatan Bank Pada Bank Umum Swasta Nasional Devisa. Journal of Business and Banking. Volume 4, No. 2, November 2014, pp. 217 - 230.

xix. Daniri, M. A. dan A. I. Simatupang., 2009. Rekayasa Pelaporan Keuangan: Isu Akuntansi Atau Governance?, Forum for Corporate Governance in Indonesia, http:/ / www.fcgi.or.id.

xx. Davis, J. H., Schoorman, F. D., \& Donaldson, R. (1997). Toward a stewardship theory of management. Academy of Management Review, 22(1), 20-47.

xxi. Dendawijaya, Lukman (2009). Manajemen Perbankan. Jakarta: Ghalia Indoensia.

xxii. Dewi, Farida Shinta., Arifati, Rina dan Andini,Rita. (2016). Analysis Of Effect Of CAR, ROA, LDR, Company Size, NPL, AND GCG To Bank Profitability (Case Study On Banking Companies Listed In BEI Period 2010-2013). Journal of Accounting, Vol 2 No.2. 
xxiii. Djamaludin, Said et.al. The Effectof the Fundamental Factors Againts Bank Stock Price Listed in Indonesia Stock Exchange Period 2013 - 2015. International Journal of innovative research \& development. Vol.11, NO.1, pp.42-52.

xxiv. Dupla KS. (2017). OJK: Laba perbankan akan tumbuh satu digit di 2017. http:/ / keuangan.kontan.co.id/ news/ ojk-labaperbankan-akan-tumbuh-satu-digit-di-2017 (Diakses tanggal 24 Desember 2017)

xxv. Dupla KS. (2017). Pencadangan bank BUMN tetap tinggi di 2017. http:/ / keuangan.kontan.co.id/ news/ pencadanganbank-bumn-tetap-tinggi-di-2017 (Diakses tanggal 24 Desember 2017).

xxvi. Elleuch, Sarra Hamza. (2015). Earnings management and evolution of the banking regulation The case of Tunisian banks following the IMF recommendations. Journal of Accounting in Emerging Economies.Vol. 5 No. 2, pp. 150-169.

xxvii. Frederick, Choi D.S. and Gary, Meek K.. (2005). Akuntansi Internasional, Ed 6 Buku 2. Salemba Empat .Jakarta.

xxviii. Garp, Philippe Jorion. (2007). Financial Risk Manager. $4^{\text {th }}$ ed. John Wiley \& Sons, Inc., Hoboken. New Jersey.

xxix. Giordana, Gaston A and Ingmar Schumacher. (2017). An Empirical Study on the Impact of Basel III Standards on Banks'Default Risk: The Case of Luxembourg.J.Risk Financial Management. Vol.10, 8; doi:10.3390/jrfm10020008.

xxx. Golja, Tea., Nizic, Marinela Krstinic., dan Paulisic, Morena. (2011). Perspectives of Corporate Governance in Croatian Banking Sector. International Journal of Economics and Financial Issues. Vol.1, No.3.pp.78-87.

xxxi. Hery. (2015). Manajemen Resiko Bisnis. Pnerbit Grasindo. Jakarta.

xxxii. Hue, Nguyen Thi Minh. (2015). Non-Performing Loans: Affecting Factor for the Sustainability of Vietnam Commercial Banks. Journal of Economics and Development, Vol.17, No.1, April 2015, pp. 93-106

xxxiii. Hull, John C. (2012). Risk Management and Financial Institutions. $3^{\text {rd }}$ edition. John Wiley \& Sons, Inc., Hoboken. New Jersey.

xxxiv. Idoliany dan Wiryono (2014) The Effect Of Credit Risk And Interest Rate Risk On Microfinance Institution's Financial Sustainability: The Case Of Middle Java Conventional With Three Different Categories Of Assets. Journal of Business and Management, Vol.3, No.1,pp. 33-48

xxxv. Ihsan (2016). Kualitas Penerapan Good Corporate Governance Pada Bank Umum Syariah Di Indonesia Serta Pengaruhnya Pada Kinerja Keuangan. Jurnal Ekonomi Islam. Vol.7, N.2

xxxvi. Imam Ghozali dan Hengky Latan. (2014). Partial Least Squares. Konsep, Metode dan Aplikasi Menggunakan Program WarpPLS 4.0, Semarang: Badan Penerbit Universitas Diponegoro.

xxxvii. Jorion., Philippe. (2007). Financial Risk Manager Handbook. Fourth Edition. John Wiley \& Sons, Inc. Canada.

xxxviii. Jumingan. (2008). Analisis Laporan Keuangan. Bumi Aksara. Jakarta.

xxxix. Kaihatu, T. S., 2006. Good Corporate Governance dan Penerapannya di Indonesia, Jurnal Manajemen dan Kewirausahaan, Vol. 8, No. 1, hal. 1-9.

xl. Kamyarta Ariwangsa., 2007. Pengaruh Mekanisme Corporate Governance Terhadap Biaya Hutang. Skripsi Fakultas Ekonomi Unversitas Airlangga, Surabaya.

xli. Kasmir. (2003). Manajemen Perbankan.. Jakarta : PT Raja Grafindo Persada. (2010). Analisa Laporan Keungan. Edisi Ke 3. Jakarta: Rajawali Pers.

xlii. Kasmir. (2008). Analisis Laporan Keuangan. Raja Grafindo Persada. Jakarta.

xliii. Kasmir. 2014. Manajemen Perbankan. Edisi Revisi. PT.RajaGrafindo Persada, Jakarta.

xliv. Khabibah dan Mutmainah (2013). Analisis Hubungan Corporate Social Responsibility dan Corporate Financial Performance Pada Perbankan Syariah Di Indonesia. Diponegoro Journal Of Accounting. Vol.2 No.3,pp.1-11

xlv. Khalib,Muniroh; Abdul-Rahman,Aisyah dan Janor, Hawati . The impact of efficiency on liquidity risk in Malaysian banking institutions. Jurnal Pengurusan. Vol.47/

xlvi. Kock, Ned. (2013). WarpPLS 4.0 User Manual. ScripWarp System, Loredo, Texas USA.

xlvii. Kumala Ratih, Ni Made Dwi(2013). Pengaruh risiko kredit pada kinerja perusahaan dengan Good Corporate Governanve sebagai variabel pemoderasi. E-Jurnal Ekonomi dan Bisnis Universitas Udayana.Volume.02.No.04, pp. 265-277.

xlviii. Kurniawansyah, Doni dan Mutmainah, Siti. (2013). Analisis Hubungan Financial Performance Dan Corporate Social Responsibility (Studi Empiris pada Perusahaan Perbankan yang Terdaftar di Bursa Efek Indonesia). Diponegoro Journal Of Accounting.Vol 2, N. 2, pp.1.

xlix. Lai. (2014). Corporate Governance and Financial Performance of Bank in Asian Regions and Recommendations. Asian Journal of Finance \& Accounting, Vol. 6, No. 2.

l. Margaretha (2012). Analisis CSR dan kinerja keuangan studi empiris pada perusahaan yang terdaftar pada indeks SRI KEHATI. Jurnal Manajemen Teori dan Terapan. Vol.5 No. 2.

li. Miah S.M. Mohi Uddin dan Alam, Mohammed Robiul. (2017). Corporate Governance in context of Performance \& Sustainability: A Case Study on Banking Industry in Bangladesh. IOSR Journal of Business and Management (IOSRJBM). Vol 19, PP 87-94.

lii. Notoatmojo.M, Iqbal dan Rahmawaty, Anita. (2016). Analisis faktor-faktor yang mempengaruhi financial sustainability ratio pada Bank umum Syariah di Indonesia periode 2010 - 2014. Jurnal Ekonomi Syariah. Vol.4, No.1,pp.20 - 42.

liii. Otoritas Jasa Keuangan, Departemen Penelitian dan Pengaturan Perbankan, (2014). Kerangka Basel III Liquidity Coverage Ratio (LCR). Consultative Paper. Jakarta.

liv. Overheu, Christina James dan Cotter,Julie. (2009). Corporate Governance, Sustainability and the Assessment of Default Risk. Asian Journal of Finance \& Accounting. Vol.1, No.1:E1. 
lv. Pan, Haiying dan Gu, Chaochao (2013). An Evaluation of the Sustainable Development Lever of Listed Commercial Banks in China. Research in World Economy. Vol. 4, No.2.

lvi. Permatasari, Ika dan Novitasary, Retno.(2014). Pengaruh Implementasi Good Corporate Governance terhadap Permodalan dan Kinerja Perbankan di Indonesia: Manajemen Risiko Sebagai Variabel Intervening. Jurnal Ekonomi Kuantitatif Terapan. Vol.7 No.1.

lvii. Pitelis, C.N. (2013). Towards a more 'ethically correct' governance for economic sustainability. Journal of Business Ethics, vol.118,pp. 655-665.

lviii. Pratiwi, Caecilia Widi dan Tesniwati, Rini.(2013). Pengaruh Penerapan IFRS Terhadap Kinerja Bank Melalui Tata Kelola Perbankan Yang Baik. Proceeding PESAT (Psikologi, Ekonomi, Sastra, Arsitektur \& Teknik Sipil), Bandung, 8-9 Oktober 2013. Vol. 5 Oktober 2013.

lix. Pricewaterhouse Coopers Consulting Indonesia, (2016). Sustainability Reporting: Global Reporting Initiative (GRI) G4. www.pwc.com/

lx. Rao. K, Sambasiva dan Jirra, Teshome Dula. (2017). Corporate governance, diversification, and risk management in commercial banks of Ethiopia. International Journal of Commerce and Management Research. Vol.3, pp. 85-90.

lxi. Ratnovski, Lev. (2013). Liquidity and Transparency in Bank Risk Management. Research Departmen. Stijn Claessens.

lxii. Rosalina, Dessy. (2017). Sisihkan CKPN, Bank MNC rela telan rugi bersih. http:/ / keuangan.kontan.co.id/ news/ sisihkan-ckpn-bank-mnc-rela-telan-rugi-bersih (Diakses tanggal 24 Desember 2017).

lxiii. Roziq dan Danurwenda (2015) Pengaruh Good Corporate Governance Terhadap Corporate Social Responsibility Melalui Risiko Bisnis Dan Kinerja Keuangan Pada Bank Umum Syariah Di Indonesia. Jurnal Ajuntansi Unuversitas Jember, v. 10, n.1

lxiv. Sarwono, Aris Eddy dan Sunarko M. Rofiq. (2015) . Pengaruh Vaviabel Rasio Keuangan Terhadap Financial Sustainability Ratio Pada Bank Campuran Periode 2011-2013. Eksplorasi. Vol XXVII No.2.

lxv. Shah, Mamta. (2013). BASEL-3 and Its Impact On Indian Banking Sector. Journal of Indian Research, Vol.1.No.1, pp.5358.

lxvi. Sofyan and Anggono (2014) Liquidity Coverage Ratio Forecasting on Indonesia 19 Commercial Banks:Comparative Analysis among State-owned, Private, and Foreign Banks in period 2008 - 2013". International Conference on Trends in Economics, Humanities and Management (ICTEHM'14), Thailand, 13-14 Aug 2014

lxvii. Sofyan, Yuvizar Putra Pratama dan Anggono, Achmad Herlanto. (2015). The Effect of Risk Based Bank Rating Components towards Earnings on 19 Indonesian Commercial Banks in Period 2005-2014. Australian Journal of Accounting, Economics and Finance. Vol.1 No.1.

lxviii. Stephen A.Ross ,Randolph W.Westerfi eld, Bradford D.Jordanm. (2010). Fundamentals of Corporate Finance. Risk Management In Banking, 9th ed. McGraw-Hill/ Irwin, a business unit of The McGraw-Hill Companies, Inc.,. Americas, New York, NY.

lxix. Stone, M (1974). Cross-Validatory Choice and Assessment of Statistical Predictions, Journal of the Royal Statistical Society (36): 111-147.

lxx. Sugiyono. 2013. Metode Penelitian Bisnis, Alfabeta, Bandung.

lxxi. Taktak, Neila Boulila dan Mbarki, Ibtissem. (2014). Board characteristics, external auditing quality and earnings management Evidence from the Tunisian banks. Journal of Accounting in Emerging.Vol. 4 No. 1, pp. 79-96.

lxxii. Syed, Z., dan Safdar A. 2009. The Impact of Corporate Governance on the Cost of Equity: Empirical Evidence from Pakistani Listed Companies. The Lahore Journal of Economics, Vol. 14, hal. 139-171.

lxxiii. Sawidji Widoatmojo. 2015. Pengetahuan Pasar Modal Untuk Konteks Indonesia. Jakarta: Kompas Gramedia

lxxiv. Tobing, Adil; Arkeman, Yandra., Sanim,Bunasor dan Nuryartono.R, Nunung. Pengaruh Penerapan Good Corporate Governance terhadap Tingkat Kesehatan dan Daya Saing di Perbankan Indonesia. Jurnal Manajemen Teknologi. Vol.12.No.3.

lxxv. Umar, Husein. (2013). Desain Penelitian MSDM dan Perilaku Karyawan, Penerbit PT. Rajagrafindo Persada, Jakarta.

lxxvi. Undang-Undang No. 7/ 1992 tentang Perbankan

lxxvii. Undang-Undang Perbankan No.10/ 1998 sebagai pengganti UU No.7/ 1992.

lxxviii. Wold, Herman. (1982). Soft Modeling the Basic Design and Some Exten, In: Jorekog K.G. and Wold, H (Eds) System Indirect Observation, Causal, Structure, Prediction, Vol. II. North-Hollad, Amsterdam: 1-54.

lxxix. Yam, Jim Hoy. (2016). "Impact of Macroeconomics and Bank Specifics on Nonperforming Loans and Banking Sustainability Performance". International Journal of Innovation and Applied Studies, Vol. 18 No. pp. 972-989.

lxxx. Yudistira. LCR naik, ketahanan bank hadapi krisis meningkat. Selasa, 17 Mei 2016/ 20:03WIB,www.keuangan.kontan.co.id.http:/ / keuangan.kontan.co.id/ news/ lcr-naik-ketahanan-bank-hadapikrisis-meningkat 